\title{
Editorial
}

\section{The Innovation Agenda}

In 2010, the Association of College \& Research Libraries released The Value of Academic Libraries: A Comprehensive Research Review and Report and launched not only its "Value of Academic Libraries" (VAL) initiative (http:// www.acrl.ala.org/value/), but also a continuing series of studies seeking to

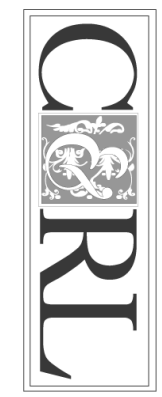
answer the Report's call to design new approaches to library assessment. ${ }^{1}$ Among the chief tasks of that report were to define what we mean by "value" when we discuss academic libraries, and to articulate specific ways in which we might study, document, and communicate the contributions that libraries and librarians make to teaching, learning, scholarship, service, and other goals valued by our institutions. In 2010, "value" was a critical concept for academic libraries to embrace, engage, and explore if they were to remain part of the broader discourse about what matters in higher education, and the fruits of this ongoing effort will be on display in an upcoming issue of this journal, which features reports on research conducted as part of the Assessment in Action project (http://www.ala.org/acrl/AiA). In 2015, there is another critical, and equally ill-defined, concept requiring our attention, and the word we associate with that concept is "innovation."

"Innovation" appears as an identifiable goal in seemingly every strategic plan currently in use or in development, whether in the library, the university, or outside the academy. Broad recognition of "innovation" as a measurable institutional characteristic in higher education gained ground this year when U.S. News \& World Report released its inaugural ranking of "Most Innovative Schools." ${ }^{2}$ As with other U.S. News rankings, this one was based on peer assessment. In this case, higher education leaders were asked to nominate institutions making "the most innovative improvements in terms of curriculum, faculty, students, campus life, technology or facilities." ${ }^{3}$ What was meant by "innovative" was left to respondents to decide, but we may glean one university's view of innovations that matter from the description provided by President Dennis Holtschneider in his announcement of DePaul University's inclusion on the list: “DePaul's faculty has a culture of developing cutting-edge programs quickly ... [and] designing amazing facilities, like The Theatre School building and the new Scholar's Lab and media:scape collaboration stations in Richardson Library." Other efforts noted in DePaul's announcement included the creation of an "innovation lab" in the College of Communication equipped with technology designed to track social media across platforms and the launch of an interdisciplinary Center for Data Mining and Predictive Analytics. ${ }^{4}$ One year earlier, Holtschneider celebrated the opening of an "innovation lab" at DePaul College Prep High School, one comprised of "a collection of classrooms dedicated to hands-on activities where students can apply what they've learned in the classroom to make everything from jewelry and visual art to films and e-textiles." ${ }^{\text {In }}$ each case, "innovation" was defined by changes to the curriculum and facilities allowing an educational institution to pursue new approaches to the core missions of teaching and learning, and promoting a holistic approach to learning that goes beyond the classroom to foster community engagement with the educational mission. Innovation of this type is found in other Chicago institutions, e.g., Chicago Public Library, which has gained national attention for YOUMedia, its "21st century teen digital learning space," and for its leadership in the "Chicago City of Learning" initiative. ${ }^{6}$ 
Innovation defined by contributions to the advancement of teaching and learning or by community engagement is very different from the innovation valued by another set of rankings published this year. For Reuters, "innovation" is defined by a suite of metrics focused on the responsibility of higher education "to convert public funding into knowledge and products that help drive the global economy." Stanford University, holding the top spot in this ranking, was noted for the revenue generated by companies founded by entrepreneurs educated or employed by Stanford, as well as the number of times articles and patents registered to Stanford researchers were cited by others in the academic or corporate sectors. ${ }^{7}$ The impact of taking this approach to defining innovation can be seen in the ways in which entire categories of institutions were eliminated from consideration early in the process, e.g., if their researchers had not filed a sufficient number of patents. ${ }^{8}$ For Reuters, innovation in higher education is defined by the capacity to "reliably produce original research, create useful technology, and have the greatest economic impact." ${ }^{\prime \prime}$ The Reuters list complements another recent addition to the global rankings, i.e., the "innovation indicators" identified by Times Higher Education (THE). THE focuses on university-industry partnerships that allow institutions of higher education "to enhance their research, find new applications for their work and boost revenues." ${ }^{10}$ Reuters acknowledges that its approach to measuring innovation may result in smaller institutions being overlooked even if they possess pockets of innovative practice, e.g., "[a] small liberal arts school might rank low for overall innovation, but still operate one of the most innovative computer science departments in the world."11 What both Reuters and THE appear to ignore, however, is that they have mistaken the filing of patents, the quantity of research income derived from industry partnerships, and the economic impact of academic research for everything that might be considered "innovative" in higher education. This truncated view of what "innovation" means, and how it might be measured, has significant potential to influence leadership support for academic libraries and the services they provide.

Innovation of the type prized by Reuters can certainly be found in libraries, and our contributions to this type of innovation can be seen in the work being done at places like North Carolina State University's James B. Hunt, Jr. Library. ${ }^{12}$ Public libraries also support this sort of innovation, as in the case of the Alexandria Co-Working Network, which brings together the expertise of Arizona State University's Entrepreneurship and Innovation Group and the community access provided by public libraries. ${ }^{13}$ Supporting economic advancement is also one of the strategic focus areas for Chicago Public Library..$^{14}$ When speaking to academic leaders or our colleagues, however, we would argue that innovation in academic libraries must be considered in many more ways and, frankly, in more appropriate ways, if we are to have a true sense of the library as a component of the university's innovation agenda. We must focus on a definition of innovation that looks beyond economic indicators to the educational mission of the academy, e.g., a novel approach or application of an existing idea, process, or invention that leads to increased commitment to an institution's mission, and to meaningful impact for an institution's community.

Innovation of this type may relate to changes in the library service program, or to ways in which librarians contribute to changes in teaching, learning, or scholarship on campus. Innovation may involve collaboration with student affairs professionals to consider the impact of co-curricular spaces on student learning, or with community leaders to re-think the role of the academic library as a contributor to K-12 student success. Innovation may involve recruiting a digital scholarship specialist whose focus is on extending the reach of undergraduate research through open access publishing, or adopting an approach to space planning that allows the library to support new models of teaching and research. Innovation may be found in the development of a 
peer leadership approach to student employment, or in the provision of technologies that promote faculty collaboration across the traditional boundaries of established disciplines. Innovation in library practice can be seen in the evolution of our thinking about our role as teachers, moving from training in the use of tools, to instruction in how to think critically about information sources, to focusing on the "intersections" of information literacy, media literacy, data literacy, and scholarly communications that allow us to contribute more effectively to the development of students as creators of digital content and as engaged digital citizens. Each of these innovations is just as important as our taking responsibility for research data management or the provision of access to an array of "maker" spaces and tools, but some are more commonly featured in discussions of innovation in academic libraries than others. Any of these innovations, moreover, may be of greater value to one academic community than another depending on the local institutional mission and focus. Our definition of innovation in academic libraries should not follow a model of narrowly defined metrics, but should reflect the diversity of our academic communities.

A broader definition of innovation is inclusive of institutions that focus on access, rather than selectivity, or on teaching, rather than research. A broader definition of innovation is inclusive of institutions that focus on leadership in a given community or discipline, rather than recognizing only the most comprehensive institutions (or those with a specific mandate to foster industry partnerships and technology transfer). A broader definition of innovation does not privilege one set of activities over another as being more valuable to our communities or our future as librarians. Innovators, as Purdue's Deba Dutta noted, create value, and value, as we have seen through the VAL initiative, is often best understood within the local context. ${ }^{15}$

A broader and more contextualized approach to understanding innovation in academic libraries is important for two reasons.

First, it counters the prevailing narrative that innovation is intimately tied to technology and the technology industry. Innovation does indeed occur in computer science, engineering, and business, but innovation is also very much present in the work of the philosopher, critical theorist, and sociologist. Innovation can be fostered in maker spaces and visualization labs, but also in information literacy instruction and special collections. Innovation may result in patents and start-ups, but also in poems and prose. At the University of Nevada - Reno, the library provides a maker space not simply to prototype new inventions, but also to visualize abstract mathematical concepts and to engage students in learning in a new way. ${ }^{16}$ If we focus on business spin-offs as the primary measure of academic innovation, we ignore the basic fact that the overarching mission of academic libraries, and academia in general, is not to emulate or stimulate commerce, but to foster learning and understanding.

The second way in which a broader definition of innovation is required can be seen in the profession of librarianship itself. It is easy to argue that innovation is not the job of librarians if innovation is defined in the narrow worldview of Silicon Valley. There is nothing fundamental to librarianship that tasks a librarian with developing a new app, but it is the job of every librarian to make positive change in his or her institution and for those with whom he or she works. Librarianship is a growing and changing profession that seeks out the best way to accomplish a task, and often does so by adapting the work of others across disciplines and from other fields. Innovation happens in librarianship precisely on the margins where our work touches upon the work of our students and our colleagues (including our colleagues in other types of libraries), and not only on the margin marked by new technology.

This is not unique to librarians. The academic context itself is one of building and diffusing new knowledge in society. Faculty and students have a special status in our 
society because their primary mission is finding new ways of understanding how to make a positive change in the world. That may happen in the classroom, a particle collider, a studio, or an office. Innovation is the core business of all of academia, and if we too narrowly define innovation according to one model-one developed as part of commercial pressures from the technology industry - so, too, do we narrow the scope of academia, and slide ever closer to a corporate model of the college, the university, and the library.

College $\mathcal{E}$ Research Libraries has provided a venue for many studies of innovation in academic libraries, both in terms of the application of new technologies to library practice and in terms of the expansion of academic library services into new areas that support the changing landscape of higher education. The attention given by senior academic administrators to innovation and the emergence of an array of new rankings in this area suggest that academic libraries will be regularly asked to demonstrate their contributions to the innovation agenda. Our libraries and our communities will be better served if we are able to articulate our contributions to that agenda in a manner consistent with our professional values and the distinctive character of our libraries and institutions. Just as ACRL launched a new approach to how we study and articulate the "value" of the academic library to the higher education enterprise, we think the time is right for a similar, and equally inclusive, approach to the study of "innovation."

\section{Scott Walter \\ DePaul University}

R. David Lankes

Syracuse University

\section{Notes}

1. Megan Oakleaf, The Value of Academic Libraries: A Comprehensive Research Review and Report (Chicago: Association of College \& Research Libraries, 2010).

2. U.S. News \& World Report, "Most Innovative Schools," accessed October 6, 2015, http:// colleges.usnews.rankingsandreviews.com/best-colleges/rankings/national-universities/innovative

3. U.S. News \& World Report, "Most Innovative Schools Methodology," accessed October 6, 2015, http://www.usnews.com/education/best-colleges/articles/most-innovative-schoolsmethodology

4. DePaul University, “U.S. News \& World Report Lists DePaul University as 'Innovative School,'" accessed October 6, 2015, http://newsroom.depaul.edu/NewsReleases/showNews. aspx?NID=2936

5. Mina Bloom, "Gordon Tech Renamed DePaul College Prep, Debuts Large Innovation Lab," DNAinfo | Chicago (September 22, 2014), accessed October 17, 2015, http://www.dnainfo. com/chicago/20140922/irving-park/gordon-tech-renamed-depaul-college-prep-debuts-largeinnovation-lab

6. Chicago Public Library, "About Us: YOUMedia," accessed October 17, 2015, http://www. chipublib.org/youmedia/; Chicago City of Learning, "What is Chicago City of Learning," accessed October 24, 2015, https://chicagocityoflearning.org. Other CCOL partners include Chicago Public Schools, Chicago Park District, DePaul University, and the Mozilla Foundation.

7. David Ewalt, “The World's Most Innovative Universities," Reuters.com (September 15, 2015), accessed October 17, 2015, http://www.reuters.com/article/2015/09/15/idUSL1N11K16Q20150915

8. "Methodology: Ranking the World's Most Innovative Universities," Reuters.com (September 15, 2015), accessed October 17, 2015, http://www.reuters.com/most-innovative-universities/ methodology

9. Ewalt, "The World's Most Innovative Universities."

10. Ellie Bothwell, "Which Universities are the Most Innovative?," Times Higher Education (August 20, 2015), accessed October 17, 2015, https://www.timeshighereducation.com/features/ which-universities-are-the-most-innovative 
11. Ewalt, "The World's Most Innovative Universities."

12. North Carolina State University Libraries, "Hunt Library Vision," accessed October 23, 2015, http://www.lib.ncsu.edu/huntlibrary/vision

13. Arizona State University, "Alexandria Co-Working Network," accessed October 23, 2015 , https://entrepreneurship.asu.edu/sites/default/files/files/Alexandria-Co-Working-Network_2013. pdf

14. Chicago Public Library, "Building the Library of the Future: 2015-2017 Strategy," accessed October 24, 2015, https://www.chipublib.org/wp-content/uploads/sites/3/2014/06/CPL-strategicplan-2015.pdf

15. Deba Dutta, "Educating to Innovate," Inside Higher Ed (October 16, 2015), accessed October 17, 2015, https://www.insidehighered.com/views/2015/10/16/research-and-recommendationsabout-encouraging-innovation-essay

16. Chrystie Hill, Merrilee Proffitt, and Sharon Streams, eds., "IMLS Focus: Learning in Libraries" (May 14, 2015), accessed October 23, 2015, https:/www.imls.gov/sites/default/files/ publications/documents/imlsfocuslearninginlibrariesfinalreport.pdf

\section{Errata}

In the July 2015 issue (76:566-586), Felly Chiteng Kot's affiliation was listed as "Institutional Research Analyst for the Office of the Provost, Nazarbayev University, Kazakhstan." While this is his current affiliation, at the time of the study he was Institutional Research Associate within the Center for Higher Education Research and Analytics at Georgia State University (Atlanta, Georgia). He can be contacted at felly. chiteng@gmail.com. We regret any confusion. 